\title{
Maria Cebula
}

Międzyuczelniany Instytut Muzyki Kościelnej w Krakowie

\section{Komunikat z XI Dni Muzyki Kościelnej w archidiecezji krakowskiej}

Po raz jedenasty mieliśmy okazję pochylić się nad wyjątkowością sacrum w muzyce podczas XI Dni Muzyki Kościelnej w archidiecezji krakowskiej pod patronatem kardynała Stanisława Dziwisza metropolity krakowskiego. Wzorem ubiegłego roku przewodnią myślą dni muzyki kościelnej było zagadnienie ekumenizmu w muzyce, tym razem jednak skłoniliśmy się ku liturgii i muzyce Kościoła anglikańskiego.

Tegoroczne dni zostały zainaugurowane w sposób szczególny. W kościele Opactwa św. Wojciecha Mniszek Benedyktynek odbył się 14 listopada 2015 roku koncert promujący płytę żeńskiego zespołu wokalnego Flores Rosarum. Koncert był zwieńczeniem projektu „Muzyka klasztorów żeńskich na terenie Małopolski w epoce średniowiecza”. Rozpoczęcie obchodów dni muzyki kościelnej tym koncertem wskazuje na szczególny szacunek dla tego, co jest źródłem i największym bogactwem muzyki sakralnej - chorału gregoriańskiego.

15 listopada w bazylice mariackiej miał miejsce koncert dra Witolda Zalewskiego - pierwszego organisty katedry wawelskiej. Mieliśmy wtedy przyjemność wysłuchać utworów Jana Sebastiana Bacha, Cesara Francka i Mieczysława Surzyńskiego. Artysta zaproponował szeroki przekrój programowy, co pozwoliło w pełni ukazać piękno i możliwości brzmienia organów bazyliki, a także sprawiło, że każdy z przybyłych miłośników muzyki znalazł coś dla siebie. Warto również zwrócić uwagę, iż dr Witold Zalewski kładzie szczególny nacisk na promowanie muzyki organowej polskich kompozytorów, co konsekwentnie realizuje, koncertując zarówno w naszym kraju, jak i poza granicami Polski i Europy.

17 listopada w kościele św. Stanisława BM zorganizowano koncert z cyklu: „Z myślą Benedykta XVI”. Koncerty te organizowane są jako wyraz wdzięczności za wręczony 4 lipca 2015 roku doktorat honoris causa papieżowi emerytowi przez Uniwersytet Papieski Jana Pawła II oraz Akademię Muzyczną w Krakowie. Krótką prelekcję pod tytułem Benedykt XVI jako propagator i obrońca soborowego postulatu o „nobilis pulchritudo” w liturgii wygłosił ks. dr hab. Robert Tyrała, dyrektor Międzyuczelnianego Instytutu Muzyki Kościelnej w Krakowie, zaś wykonawcami 
byli studenci tegoż Instytutu - Emilia Stefańska, Maria Cebula, Piotr Windak i Paweł Rymarczyk. W świątyni zabrzmiały utwory organowe Bacha, Widora, Pachelbela oraz Dupré, a dodatkowo usłyszeliśmy trzy utwory wokalno-instrumentalne w wykonaniu Piotra Windaka (tenor): arię Ermunt're dich z Kantaty 180 Bacha oraz arię Ev'ry Valley i recytatyw Comfort ye z oratorium Mesjasz Haendla. Piotrowi Windakowi akompaniowała s. dr hab. Susi Ferfoglia ucząca gry na organach w Międzyuczelnianym Instytucie Muzyki Kościelnej w Krakowie.

19 listopada w kolegiacie św. Anny odbył się koncert organowy prof. Krzysztofa Latały. W jego wykonaniu mogliśmy usłyszeć dzieła Bacha: 8 matych preludiów i fug (BWV 553-560), Fuge g-moll (BWV 578) oraz Fantasie G-dur (BWV 572).

Kolejnego dnia, w siedzibie Archidiecezjalnej Szkoły Muzycznej im. ks. kard. Franciszka Macharskiego rozpoczął się pierwszy etap VIII Krakowskiego Konkursu Młodych Organistów, w którym wzięło udział dziesięcioro utalentowanych muzyków.

Podczas gdy 21 listopada w Państwowej Ogólnokształcącej Szkole Muzycznej II stopnia im. Fryderyka Chopina rozstrzygały się losy drugiego etapu konkursu, w archidiecezji krakowskiej miało także miejsce doroczne spotkanie formacyjno-warsztatowe organistów. Rozpoczęło się uroczystą Eucharystią, kolejno odbyła się właściwa część warsztatowa, którą zwieńczono koncertem organowym. Tego samego dnia wieczorem na Akademii Muzycznej ogłoszone zostały wyniki konkursu młodych organistów oraz koncert laureatów. Szanowne jury, którego przewodniczącym był prof. Józef Serafin, pierwszą nagrodę przyznało Maciejowi Lewandowiczowi z Wrocławia.

22 listopada w kościele Najświętszej Maryi Panny Matki Kościoła w Jaśkowicach odbył się koncert w wykonaniu Joanny Święszek (mezzosopran), Łukasza Lelka (baryton) oraz Dawida Rzepki (organy). Usłyszeliśmy utwory organowe z repertuaru Jana Sebastiana Bacha - Preludium i fuga c-moll BWV 549 oraz Preludium g-moll BWV 535, a także Felixa Mendelssohna-Bartholdy'ego - Preludium i fuga c-moll op. 37. Wśród utworów wokalno-instrumentalnych wykonano dzieła Jerzego Friedricha Haendla, Antonia Vivaldiego, Gabriela Faure oraz Camille’a Saint-Saens’a. Warto zaznaczyć, iż Łukasz Lelek i Dawid Rzepka są absolwentami Międzyuczelnianego Instytutu Muzyki Kościelnej w Krakowie.

23 listopada w siedzibie Archidiecezjalnej Szkoły Muzycznej im. Franciszka Macharskiego oraz Międzyuczelnianego Instytutu Muzyki Kościelnej miała miejsce próba otwarta chóru studentów muzyki kościelnej, którą poprowadził Andrew Reid - dyrektor The Royal School Of Church Music z Wielkiej Brytanii. Spotkanie było bardzo wyjątkowe, dyrygent stosował nowatorskie rozwiązania i tym samym wnosił świeże spojrzenia na przygotowywany przez chór repertuar.

Kolejnego dnia, 24 listopada, w Akademii Muzycznej w Krakowie miała miejsce Międzynarodowa Konferencja Naukowa, której tytuł brzmiał: „Muzyka 
Kościoła anglikańskiego - wspólne źródło, odmienne tradycje?”. Sesję rozpoczął prof. dr hab. Zdzisław Łapiński, rektor Akademii Muzycznej w Krakowie, całość zaś moderował ks. dr hab. Robert Tyrała. Pierwszy wykład zaprezentował Andrew Reid - dyrektor The Royal School Of Church Music (Wielka Brytania), a jego tytuł brzmiał następująco: English Choral Music Repertoire in Relation to the Development of the Anglican Liturgy. Prelegent przedstawił nam historię i ewolucję muzyki chóralnej w odniesieniu do rozwoju anglikańskiej liturgii. Początkowo bowiem muzyka chóralna miała swoje miejsce tylko w klasztorach, natomiast w kościołach parafialnych oficjum nie było śpiewane - księża modlili się sami.

Drugim prelegentem był Paul Trepte - dyrygent Ely Cathedral Choir (Wielka Brytania), który zaprezentował wykład English Cathedral Choirs. Paul Trepte przekazał nam wiele cennych informacji dotyczących pracy katedralnego chóru w Ely oraz organizacji przykatedralnej szkoły z internatem, w której szkoleni są młodzi artyści. Opowiedział także, w jaki sposób chórzyści doskonalą swoje umiejętności - jest to bowiem nie tylko nauka wspólnego śpiewu, ale także szerokie spektrum dydaktyczne, w którym młodzi chłopcy uczą się przyznawania do popełnianych błędów oraz wskazywania ich u siebie nawzajem, co daje bardzo wymierne korzyści. Praca w Ely Cathedral Choir jest wielkim wyzwaniem, ale jak mieliśmy przyjemność słyszeć na koncercie, trud włożony w przygotowanie przynosi doskonałe efekty.

Trzeci wykład: The History of the Anglican Liturgy wygłosił Robert Jones - diakon kościoła w Worcester (Wielka Brytania). Prelegent zaprezentował nam historię oraz główne prawa obowiązujące w anglikańskiej liturgii oraz przybliżył sylwetki głównych reformatorów i teologów. Duchowny, omawiając istotę doktryn anglikańskich, wypowiedział znamienne słowa, które bardzo zapadły mi w pamięć, a mianowicie że liturgia jest jak „zabawa dzieci przed obliczem Boga” oraz że jest „podróżą do samego Boga”.

Sesja miała wyjątkowy charakter, nie tylko ze względu na zgłębianie tajników muzyki częściowo dla nas odległej, ale także z powodu czynnego uczestnictwa podczas wykładów chóru z katedry w Ely. Żywy materiał dźwiękowy spowodował doskonałą interakcję między wykładowcą a słuchaczami.

Tego samego dnia wieczorem w bazylice mariackiej miał miejsce niezwykły koncert. Wykonawcami byli chórzyści Ely Cathedral Choir oraz częściowo Chór Międzyuczelnianego Instytutu Muzyki Kościelnej w Krakowie. W roli dyrygenta wystąpił Paul Trepte, akompaniament organowy wykonywali Edmund Adhouse oraz Andrew Reid. Chór zaprezentował utwory Herberta Howellsa, Petera Astona, Roberta Parsonsa, Henry'ego Purcella, Samuela Wesleya, Andrew Parnella, Philippa Moore’a oraz Gabriela Faure. Wieńczący koncert utwór Charles-Marie Widora - Kyrie - wykonany został wspólnie z męskim chórem Międzyuczelnianego In- 
stytutu Muzyki Kościelnej w Krakowie. Było to piękne podsumowanie i wspaniale wykonane dzieło, które sprawiło, że zatraciły się wszelkie rozróżnienia, a zabrzmiał wspólny głos w kierunku Boga, który jest ponad wszelkimi podziałami.

W środę 25 listopada w Międzyuczelnianym Instytucie Muzyki Kościelnej miała miejsce próba otwarta Ely Cathedral Choir. Dyrygent Paul Trepte wraz z chórzystami zaprezentował nam, jak wyglądają typowe zajęcia, podczas których przygotowywane były utwory na niedzielną liturgię. Charakterystycznym elementem było ćwiczenie fragmentów solowych przez różnych chłopców na przemian - każdy z nich, będąc chórzystą, może być również solistą, nie ma tu osobno wyznaczonych osób, toteż każdy może być wybrany do wykonania partii solowej. Moją uwagę przykuł także sposób zgłaszania pomyłek podczas ćwiczenia poszczególnych partii. Gdy któryś z chórzystów się pomylił, wówczas podnosił rękę w górę, dając znak, że jest świadomy popełnionego przez siebie błędu, nie przerywając tym samym narracji próby i skupienia w zespole. Młodzi chłopcy reprezentujący chór katedry w Ely mieli w sobie bardzo dużo dziecięcego uroku, ale przede wszystkim ogrom talentu i radości z tego, co robią.

Te wartościowe muzyczne doświadczenia nie miałyby miejsca, gdyby nie szczególne działania dra Krzysztofa Michałka, który zadbał o wszelkie sprawy organizacyjne. Podjął się opieki nad chórem, zarówno podczas sesji, jak i poza nią. Nie było to z pewnością łatwe zadanie, jesteśmy bardzo wdzięczni za zaangażowanie i panowanie nad wszystkimi wydarzeniami oraz znakomitą atmosferę.

Pięknym zwieńczeniem tegorocznych XI Dni Muzyki Kościelnej były uroczyste nieszpory chóralne, które odbyły się w królewskiej katedrze na Wawelu. Nabożeństwu przewodniczył ks. Robert Tyrała, natomiast kantorem był diakon Robert Jones. Śpiewy wykonywane były przez Ely Cathedral Choir, Chór Międzyuczelnianego Instytutu Muzyki Kościelnej w Krakowie oraz Chór Musica Ex Anima z Sanktuarium Miłosierdzia Bożego w Krakowie. Dyrygentami byli Paul Trepte oraz dr Krzysztof Michałek, akompaniował Edmund Aldhouse. Nieszpory miały wymiar ekumeniczny, kolejny raz mogliśmy się przekonać, że mimo różnic w doktrynach można wspólnie wielbić Boga i ku Niemu dążyć. W ten wyjątkowy sposób zakończyły się obchody XI Dni Muzyki Kościelnej w archidiecezji krakowskiej - wypełnionych ucztą muzyczną i duchową, niosących garść wiedzy i nowych doświadczeń. Niewątpliwie uczestniczenie w tych wydarzeniach było wspaniałym i głębokim przeżyciem, które sprawiło, że z niecierpliwością oczekujemy na przyszłoroczne świętowanie. 